\title{
Intake, rumen function and NDF kinetics in mature dairy heifers in Tanzania maintained on poor quality hay as affected by sugar, starch, nitrogen or mineral supplementation
}

\author{
P.S. Mlay ${ }^{1}$, A.E. Pereka ${ }^{1}$, M.R. Weisbjerg ${ }^{2}$, T. Hvelplund ${ }^{2,4}$ \\ and J. Madsen ${ }^{3}$
}

${ }^{1}$ Department of Physiology, Biochemistry, Pharmacology and Toxicology, Sokoine University of Agriculture Morogoro, Tanzania

${ }^{2}$ Department of Animal Nutrition and Physiology, Danish Institute of Agricultural Sciences, Research Centre Foulum

8830 Tjele, Denmark

${ }^{3}$ Department of Animal Science and Animal Health, The Royal Veterinary and Agricultural University Grønnegårdsvej 2, 1870 Frederiksberg, Denmark

(Received 28 October 2003; accepted 4 April 2003)

\section{ABSTRACT}

The impact on rumen function of supplements traditionally used by smallholder dairy farmers in Tanzania is reported. The supplements included sources of energy and protein (maize bran, molasses, cassava flour and sunflower cake) and an ionic feed additive called "Magadi". The experimental layout was a 5 x 5 Latin square with 14 days for adaptation to diets, 7 days in vivo digestibility and the last 7 days used for rumen evacuations. Treatments were: poor quality hay with $2.7 \mathrm{~kg}$ DM of maize bran (HMB) which was the control reflecting smallholder farmers feeding practice. Other treatments were hay with $2.7 \mathrm{~kg}$ DM of maize bran further supplemented with $0.25 \mathrm{~kg}$ DM of "Magadi" (HMG), 1.3 $\mathrm{kg}$ DM of sugar (molasses) (HMO) or $0.9 \mathrm{~kg}$ DM of starch (cassava tuber flour) (HCA). The fifth treatment was hay supplemented with $2.8 \mathrm{~kg}$ DM of farm made concentrate mixture containing (\%): maize bran (68), sunflower cake (31) and mineral powder (1) on DM basis (HFC). Five mature heifers (1/2 Boran x $1 / 2$ Friesian) were used during the trial.

Intake of $\mathrm{DM}$ and organic matter was significantly $(\mathrm{P}=0.01)$ higher with sugar $(\mathrm{HMO})$, starch (HCA) and nitrogen (HFC) supplements compared to the control (HMB). DM and OM digestibility

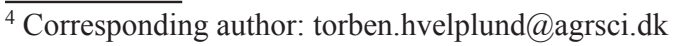


varied between 49 and 56\% and were significantly $(\mathrm{P}<0.05)$ higher for rations with nitrogen (HFC), "Magadi" (HMG), sugar (HMO) and starch (HCA) supplementation compared to the control. Rumen fluid $\mathrm{pH}$ was not greatly influenced by treatments but rumen fluid ammonia was significantly $(\mathrm{P}<0.001)$ higher in HFC compared to other treatments.

Mean total VFAs tended to be higher $(\mathrm{P}<0.1)$ in HFC $(67.0 \mathrm{mM})$ compared to the other treatments. The molar proportion of acetate was significantly $(\mathrm{P}=0.05)$ higher in HFC $(68.8 \%)$, HMG (68.4\%) and HMB (68.0\%) compared to HMO and HCA (65\% each). Rate and extent of digestible NDF degradation was significantly $(\mathrm{P}=0.02)$ higher with nitrogen $(\mathrm{HFC})\left(2.66 \% \mathrm{~h}^{-1}\right.$ and $64.2 \%$, respectively) and significantly $(\mathrm{P}=0.01)$ lower with starch $(\mathrm{HCA})\left(1.72 \% \mathrm{~h}^{-1}\right.$ and $53.0 \%$, respectively) compared to the other treatments. Starch supplementation (HCA) caused the highest passage rate for INDF $\left(2.55 \% \mathrm{~h}^{-1}\right)$ and was significantly higher than for the control diet.

It is concluded that more efficient utilization of poor quality forages occurred with increased nitrogen availability in the rumen and that the use of sugar, starch and feed additives like "Magadi" can have variable effects on intake and digestibility of poor quality forages. However, if cheap sugar and starch concentrates are available, they can be used without compromising the digestibility of the basal forage markedly.

KEY WORDS: hay, intake, digestibility, maize bran, "Magadi”, sunflower cake, cassava, molasses

\section{INTRODUCTION}

During the long dry season, tropical forages are of low quality due to high fibre content and deficiency in important nutrients like proteins that are vital for rumen microbial growth and overall animal performance (Preston and Leng, 1987; Leng, 1990). Protein supplements can increase forage intake and digestibility and improve animal performance (Poppi and McLennan, 1995). However, supplementation with protein in the absence of adequate sources of energy can lead to protein wastage (Nolan, 1990).

Moderate energy supplementation is sometimes necessary in order to increase glucose precursors thereby enhancing gluconeogenesis, acetate utilization and overall microbial growth (Cronje et al., 1991; Khalili and Huhtanen, 1991). The slow degradation of plant fibre by cellulolytic bacteria in the rumen requires a good synchrony between energy and nitrogen (N) release (Beever and Siddon, 1986).

Research on the use of various sources of nitrogen to improve utilization of poor quality roughage commonly used in Tanzania has been going on for some time (Shayo et al., 1997). However, though smallholder dairy farmers use sources of energy like maize bran, molasses and cassava, and a feed additive called "Magadi", there has been little effort to evaluate how these ingredients affect rumen fibre kinetics and overall rumen fermentation. The "Magadi" locally used in Tanzania is very close in composition to a commercial product called "Magadi"-soda naturally harvested from Lake Magadi in Kenya (Nyachoti et al., 1998). The major ingredient in Magadi soda is sodium sesquicarbonate $\left(\mathrm{NaCO}_{3} \cdot \mathrm{NaHCO}_{3} \cdot 2 \mathrm{H}_{2} \mathrm{O}\right)$. The aim of this paper was to investigate how these supplements can affect intake and digestibility 
of the poor quality hay in order to make the most efficient use of the available feed resources through strategic supplementation for improved productivity.

\section{MATERIAL AND METHODS}

\section{Animals feeds and feeding}

Five rumen fistulated, mature non-pregnant crossbred heifers (1/2 Boran x 1/2 Friesian) were used in a $5 \times 5$ Latin square design. The animals were weighed at the beginning of the experiment (IBW) and at the end of each period (FBW). The experimental period lasted for 28 days including 14 days of preliminary period followed by 7 days of estimation of voluntary feed intake (VFI), in vivo and in situ digestibility determinations and 7 days for rumen evacuations. After termination of the intake experiment, three ruminally fistulated animals fed a standard diet $(2 / 3$ hay and $1 / 3$ concentrate) were used for in situ INDF measurements.

Treatments were: 1 . low quality hay plus maize bran (HMB) to reflect normal smallholder feeding practice which was the control, 2. hay sprayed with "Magadi" suspension and maize bran (HMG) to reflect farmers who use the locally available mineral source, 3 . hay sprayed with molasses plus maize bran (HMO) to reflect farmers who have access to molasses as a sugar source, 4 . hay with maize bran plus cassava flour (HCA) to reflect farmers who could use starch sources such as cassava, 5. hay plus farm made sunflower cake-maize concentrate mixture (HFC) to reflect a situation where smallholder farmers could improve the protein content of the diet using locally available sunflower cake.

The supplements were divided into two portions, one fed at 07.30 and the remaining portion fed at 16.00. The "Magadi" was suspended in tap water and sprayed on the hay. Molasses was also sprayed on the hay.

In all treatments, poor quality hay was used as the basal diet. Urochloa spp. was the predominant grass species in the hay. The hay was chopped to small size using a hand-machete to minimise selection. The animals were fed individually ad libitum. Feeding was adjusted every day to be $10-15 \%$ in excess of the ad libitum intake the previous day. All feeds and orts were weighed daily, sampled, and prepared for subsequent analyses. The DM determination was carried out every day in both feeds and orts. Fresh and clean water was provided from automatic drinkers system equipped with flow meters where record was read at 08.00 each morning.

\section{Sampling procedures}

Faecal were collected manually from 07.00 in the morning to 07.00 the next day when it was weighed to get the amount of fresh faecal voided per day for each 
animal. Then, the faeces for each animal was thoroughly mixed in large plastic basins and a $5 \%$ sample taken. The samples were immediately frozen at a temperature of $-15^{\circ} \mathrm{C}$. At the end of the collection period (7 days), samples were de-frozen and pooled for each animal. The pooled samples were then thoroughly mixed and a sub-sample of $500 \mathrm{~g}$ taken for each animal. The samples were oven dried at $60^{\circ} \mathrm{C}$ to constant weight to determine DM content.

A day before the onset of rumen evacuation, $24 \mathrm{~h}$ rumen fluid samples were taken for determination of diurnal variations in $\mathrm{pH}$ and ammonia concentrations. The sampling times were at 07.30 (before morning feeding), 10.00, 12.00, 14.00, $16.00,18.00,20.00,22.00,24.00,02.00,04.00,06.00$ and 08.00. At the indicated sampling hours, materials from the ventral rumen sac were scooped by hand and squeezed through four layers of cheesecloth into a clean beaker. About $100 \mathrm{ml}$ of the liquid was taken. The $\mathrm{pH}$ was immediately taken using a portable $\mathrm{pH}$ meter. Then, $30 \mathrm{ml}$ of the fluid was decanted into a $50 \mathrm{ml}$ sample bottle and acidified to $\mathrm{pH} 4.0-4.5$ by adding $3 \mathrm{ml}$ of $5 \mathrm{M}$ sulphuric acid to limit loss of ammonia from the sample. Samples were put in an ice packed cool box and taken to the laboratory. In the laboratory, the samples were centrifuged at $3500 \mathrm{~g}$ for $20 \mathrm{~min}$ to precipitate the feed particles and the supernatant was put into $20 \mathrm{ml}$ test tubes, then deep frozen at $-20^{\circ} \mathrm{C}$ until analysed for volatile fatty acids and ammonia.

Rumen pool size of NDF was measured by the rumen evacuation method at 3 occasions during the last seven days of the experiments in accordance to Dado and Allen (1995) and Stensig et al. (1998). Evacuation protocols were such that a minimum time interval of $48 \mathrm{~h}$ between two evacuations was allowed to avoid any effect that might occur on subsequent measurements. Rumen evacuations were performed at 07.00 on day 24 , at 12.00 on day 27 and 17.00 on day 29 of each period.

\section{Analytical procedures}

Dry matter and ash analyses were carried out using the procedure as outlined by the AOAC (1990). A portion of the dried hay, faecal and rumen ingesta samples were ground to pass $2.5 \mathrm{~mm}$ screen for in sacco incubations, while samples intended for chemical analysis were ground to pass through $1 \mathrm{~mm}$ screen.

The indigestible proportion of NDF (INDF) was estimated from the in sacco residues after 21 days incubation in the rumen. About $2 \mathrm{~g}$ of dried milled hay, rumen ingesta and faecal samples were weighed into nylon bags (measuring $7.5 \times 10 \mathrm{~cm}$ and pore size $36 \mu \mathrm{m}$ ). The bags were incubated for 21 days in the rumen of three mature heifers fed a standard diet comprising $2 / 3$ hay and $1 / 3$ concentrate. On day 21 , the bags were removed from the rumen and washed with tap water followed by washing in domestic washing machine for a spin of 20 min using only cold water. The residues were then analysed for NDF. 
All the samples analysed for NDF were done according to the methods described by Van Soest et al. (1991). In the analyses, however, sodium sulphite and $\alpha$-amylase were omitted. CP content in samples was calculated from the nitrogen content estimated by the Kjeldal method (AOAC, 1990).

The concentration of ammonia in the ruminal fluid was estimated by a standard procedure as described by Chaney and Marbach (1962) using alkaline hypochlorite/phenol nitroprusside. The concentrations of VFAs in the ruminal fluid were determined by using a gas chromatograph (HP $6890 \mathrm{GC}$ ) coupled to peak integrator (HPGC Chemostation, Hewlett and Packard, 1990-1998) by the method by Richardson et al. (1989) with some minor modifications.

In vitro organic matter digestibility of the hay and concentrates was determined using the method of Tilley and Terry (1963).

\section{Calculations}

Estimation of duodenal flow of NDF. Rate of passage of NDF from the rumen, calculated from rumen evacuation data, should be determined from measured rumen pool size of NDF and duodenal NDF flow. Since the animals used in this study did not have duodenal fistulas, it was not possible to directly measure duodenal NDF flow, and was thus calculated assuming a hindgut digestion of $6.5 \%$ of NDF intake, using the following equation:

Duodenal NDF flow $(\mathrm{kg} /$ day $)=$ faecal NDF flow $(\mathrm{kg} /$ day $)+[(\mathrm{NDF}$ intake $(\mathrm{kg} /$ day $) \times 0.065]$

As duodenal flow of INDF equals faecal flow of INDF, the duodenal flow of digestible NDF (DNDF) was calculated as:

Duodenal flow of DNDF (kg/day) = duodenal NDF flow $(\mathrm{kg} /$ day $)-$ faecal INDF flow (kg/day).

NDF kinetics. Fractional rates of passage and digestion (referred to as rates of digestion and passage) of fibre fractions in the rumen were calculated from fibre flow and pool sizes in the rumen as previously proposed by Robinson et al. (1987) as shown below:

Rate of intake $(\mathrm{ki}) \% \mathrm{~h}^{-1}=100 / 24 \times$ daily intake $(\mathrm{kg}) /$ rumen pool size $(\mathrm{kg})$

Rate of passage $(\mathrm{kp}) \% \mathrm{~h}^{-1}=100 / 24 \times$ [calculated duodenal flow $(\mathrm{kg} /$ day $) /$ rumen pool size $(\mathrm{kg})]$

Rate of digestion $(\mathrm{kd}) \% \mathrm{~h}^{-1}=\mathrm{ki}-\mathrm{kp}$

Mean retention time (MRT) $\mathrm{h}=1 / \mathrm{kp}$

The model assumes first order-kinetics and in the current study it incorporated potentially digestible and indigestible fractions as described by Allen and Mertens (1988). 
Rumen digestibility of NDF and DNDF was estimated using a simple onecompartment model as described by Allen and Mertens (1988) as shown below:

Rumen digestibility of NDF $=\mathrm{DNDF} / \mathrm{NDF} \times(\mathrm{kd} /(\mathrm{kd}+\mathrm{kp}))$

Rumen digestibility of DNDF $=\mathrm{kd} /(\mathrm{kd}+\mathrm{kp})$

where $\mathrm{kp}$ and $\mathrm{kd}$ have been described above.

\section{Statistical analysis}

Statistical analysis was carried out by the General Linear Model (GLM) to test the differences between the means of the various parameters using the model:

Where

$$
\mathrm{Y}=\mathrm{I}+\mathrm{T}+\mathrm{C}+\mathrm{P}+\varepsilon(\text { Model } 1)
$$

$\mathrm{Y}=$ dependent variables

$\mathrm{I}=$ intercept

$\mathrm{T}=$ treatment $(\mathrm{HMG}, \mathrm{HCA}, \mathrm{HMO}, \mathrm{HFC}$ and $\mathrm{HMB})$

$\mathrm{C}=\operatorname{cow}(\operatorname{cow} 1-5)$

$\mathrm{P}=$ period $($ period $1-5)$

$\varepsilon=$ random error

Comparison between treatment means was done by PDIF in GLM. Results are reported as least square means for each treatment with standard error of the least square means. P-values were based on type II test (SAS, 1988).

\section{RESULTS}

\section{Chemical composition of feeds}

Chemical composition and in vitro organic matter digestibility of feed ingredients used during the trial are shown in Table 1. DM percent ranged from $78 \%$ in molasses to $93 \%$ in the hay. The $\mathrm{CP}$ content of the feeds varied greatly, with the concentrate mixture having the highest followed by maize bran, hay, molasses and finally cassava flour.

The CP content in cane molasses was within the range reported (1-5\%) from tropical areas (Göhl, 1981). The hay had the highest ash content $(10.9 \%)$ followed by molasses $(10.0 \%)$, cassava $(7.8 \%)$ and 5.4 and $5.1 \%$ of DM in the concentrate mixture and maize bran, respectively. As expected, the NDF content was highest in hay $(75.2 \%)$, medium in maize bran and concentrate (32 and $38 \%$ of DM), respectively and assumed to be zero in molasses.

In vitro OM digestibility results for cassava flour from two different laboratories gave incredibly low values (33 and 39\%). This was possibly due to the effects of either low nitrogen or high cyanide content that may have reduced microbial activity in the in vitro system. 
TABLE 1

The chemical composition of feeds used during the trial, $\%$

\begin{tabular}{|c|c|c|c|c|c|}
\hline & \multicolumn{5}{|c|}{ Type of feed } \\
\hline & maize bran & $\begin{array}{l}\text { formulated } \\
\text { concentrate }\end{array}$ & $\begin{array}{c}\text { cane } \\
\text { molasses }\end{array}$ & $\begin{array}{c}\text { cassava } \\
\text { flour }\end{array}$ & hay \\
\hline DM & 91.5 & 92.2 & 78.4 & 92.5 & 93.1 \\
\hline Components, \% DM & & & & & \\
\hline ash & 5.1 & 5.4 & 9.6 & 7.8 & 10.9 \\
\hline organic matter & 94.9 & 94.6 & 90.4 & 92.2 & 89.1 \\
\hline crude protein & 10.9 & 14.8 & 2.1 & 1.4 & 3.4 \\
\hline ether extract & 10.7 & 9.2 & $\mathrm{NA}^{3}$ & 0.7 & 3.0 \\
\hline NDF & 31.9 & 38.0 & NA & 13.7 & 75.2 \\
\hline INDF & 3.4 & 4.8 & NA & NA & 26.2 \\
\hline carbohydrates $^{1}$ & 73.3 & 70.5 & NA & 90.1 & 82.7 \\
\hline $\mathrm{K}$ & 0.8 & 0.7 & NA & NA & 1.4 \\
\hline $\mathrm{Ca}$ & 0.1 & 0.2 & NA & NA & 0.4 \\
\hline $\mathrm{Mg}$ & 0.3 & 0.3 & NA & NA & 0.4 \\
\hline $\mathrm{P}$ & 0.8 & 0.7 & NA & NA & 0.3 \\
\hline $\mathrm{Na}$ & 0.2 & 0.2 & NA & NA & 0.3 \\
\hline IVOMD $^{2}$ & 65.6 & 61.5 & NA & $\mathrm{AP}^{4}$ & 36.7 \\
\hline
\end{tabular}

${ }^{1} \mathrm{CHO}$ : carbohydrates; ${ }^{2} \mathrm{IVOMD}$ : in vitro organic matter digestibility; ${ }^{3} \mathrm{NA}$ : not analysed; ${ }^{4} \mathrm{AP}$ : analysed but results from two different laboratories were incredibly low (33.4 and 39.1) and not considered as reliable

Table 2 shows the amounts of supplements and additive given to the animals under the various treatments. About $2.7 \mathrm{~kg}$ DM of maize bran was offered in $\mathrm{HMG}$, $\mathrm{HCA}, \mathrm{HMO}$ and $\mathrm{HMB}$ while $2.8 \mathrm{~kg}$ DM of concentrate mixture containing 1.9 and $0.9 \mathrm{~kg}$ maize bran and sunflower cake, respectively, was given during HFC treatment. It was planned that animals during HMO treatment would consume about $1.4 \mathrm{~kg} \mathrm{DM}$ molasses. However when the final intake was calculated considering the refusals, actual molasses intake was $1.3 \mathrm{~kg} \mathrm{DM} / \mathrm{cow} /$ day. The amount of concentrates consumed (\% of total DM intake) was significantly $(\mathrm{P}<0.001)$ higher with sugar (HMO) and starch (HCA) compared to the other treatments due to the additional DM from the two supplements and not from increased consumption of hay.

TABLE 2

Amounts of supplements/feed additive given to the animals

\begin{tabular}{lccccc}
\hline \multirow{2}{*}{ Ingredient, kg DM/day } & \multicolumn{5}{c}{ Treatments } \\
\cline { 2 - 6 } & HMG & HCA & HMO & HFC & HMB \\
\hline Cane molasses & & 0.9 & 1.4 & & \\
$\begin{array}{l}\text { Cassava flour } \\
\text { Concentrate mixture }\end{array}$ & 2.7 & 2.7 & 2.7 & 2.8 & 2.7 \\
$\begin{array}{l}\text { Maize bran } \\
\text { "Magadi" }\end{array}$ & 0.3 & & & & \\
Total supplements & 3.0 & 3.6 & 4.1 & 2.8 & 2.7 \\
\hline
\end{tabular}

HMG: hay + maize bran + "Magadi"; HCA: hay + maize bran + cassava; HMO: hay + maize bran + molasses; HFC: hay + formulated concentrate; HMB: hay + maize bran

${ }^{1}$ contained $1.9 \mathrm{~kg}$ maize bran and $0.9 \mathrm{~kg}$ sunflower cake 
Shown in Table 3 is the mineral composition of "Magadi". The high ash content of "Magadi" (83\% of DM) indicates that the ingredient mainly contains minerals. The largest component was water-soluble bicarbonate (18\% of DM) that is also reflected by the high amount of carbon $(6.7 \%$ of DM).

TABLE 3

Mineral composition of "Magadi"

\begin{tabular}{lrr}
\hline & \multicolumn{2}{c}{ Proportion } \\
\cline { 2 - 3 } Component & \% in $\mathrm{DM}$ & $\mathrm{mg} / \mathrm{kg}$ \\
\hline $\mathrm{Ash}$ & 83.2 & \\
$\mathrm{Mg}$ & 2.3 & \\
$\mathrm{Ca}$ & 3.1 & \\
$\mathrm{P}$ & 0.3 & \\
$\mathrm{~K}$ & 1.3 & \\
$\mathrm{Na}$ & 14.3 & \\
$\mathrm{C}$ & 6.7 & \\
$\mathrm{Cl}$ & 1.5 & \\
$\mathrm{Cu}$ & & \\
$\mathrm{Fe}$ & 3.4 & 606.2 \\
$\mathrm{Mn}$ & & \\
$\mathrm{Zn}$ & & \\
Water soluble $\mathrm{HCO}_{3}$ & 17.6 & \\
\hline
\end{tabular}

\section{Animal health}

One heifer died with signs of East Coast fever (ECF) at the beginning of period 4 and was replaced with another heifer of nearly the same weight.

\section{Intake, flow and digestibility of nutrients}

Results of intake of the various dietary components are shown in Table 4. Hay DM intake was not significantly affected by treatments, though it tended to be higher $(\mathrm{P}<0.1)$ with nitrogen supplementation compared to the other treatments. Total DM and $\mathrm{OM}$ intake was significantly $(\mathrm{P}=0.01)$ higher with sugar (HMO), starch (HCA) and nitrogen (HFC) supplementation compared to "Magadi" (HMG) and the control (HMB) (Table 4). There was no statistically significant treatment effect on faecal flow of DM and OM (Table 5). Apparent digestibility of DM and OM varied between 49 and $56 \%$ and was significantly $(\mathrm{P}=0.05)$ higher with sugar, starch, "Magadi" and nitrogen supplementation compared to the control (Table 5).

Total nitrogen intake during the experiment varied between treatments. It ranged from 71 to $96 \mathrm{~g}$ /day with the highest value occurring with nitrogen supplementation (HFC) and the lowest with the control (HMB) and "Magadi" (HMG) (Table 4). Faecal flow of N was highest with "Magadi" and sugar supplements (54 and $53 \mathrm{~g} /$ day, 
TABLE 4

The effect of supplementation with different ingredients on dry matter (DM), organic matter (OM), ash, water and nitrogen intake

\begin{tabular}{|c|c|c|c|c|c|c|c|}
\hline & \multicolumn{5}{|c|}{ Treatments } & \multirow{2}{*}{ SEM } & \multirow{2}{*}{ P value } \\
\hline & HMG & $\mathrm{HCA}$ & HMO & $\mathrm{HFC}$ & HMB & & \\
\hline \multicolumn{8}{|l|}{ Intake } \\
\hline hay DM, kg/day & 4.69 & 4.70 & 4.53 & 5.39 & 4.48 & 0.24 & 0.1 \\
\hline total DM, $\mathrm{kg} /$ day & $7.6^{\mathrm{b}}$ & $8.3^{\mathrm{a}}$ & $8.5^{\mathrm{a}}$ & $8.2^{\mathrm{a}}$ & $7.2^{\mathrm{b}}$ & 0.24 & 0.01 \\
\hline ash, $\mathrm{kg} /$ day & $0.76^{\mathrm{ab}}$ & $0.68^{\mathrm{b}}$ & $0.82^{\mathrm{a}}$ & $0.73^{\mathrm{ab}}$ & $0.60^{c}$ & 0.03 & 0.003 \\
\hline OM, kg/day & $6.9^{\mathrm{b}}$ & $7.6^{\mathrm{a}}$ & $7.7^{\mathrm{a}}$ & $7.4^{\mathrm{a}}$ & $6.6^{\mathrm{b}}$ & 0.12 & 0.01 \\
\hline $\mathrm{DM}, \% \mathrm{BW}$ & $2.2^{\mathrm{b}}$ & $2.3^{\mathrm{a}}$ & $2.4^{\mathrm{a}}$ & $2.2^{\mathrm{a}}$ & $2.1^{\mathrm{b}}$ & 0.05 & 0.01 \\
\hline $\mathrm{DM}, \mathrm{g} / \mathrm{kg} \mathrm{W}^{0.75}$ & $93.2^{\mathrm{b}}$ & $101.1^{\mathrm{a}}$ & $102.3^{\mathrm{a}}$ & $97.8^{\mathrm{a}}$ & $88.6^{\mathrm{b}}$ & 2.48 & 0.01 \\
\hline water, 1/day & 31.3 & 29.9 & 33.5 & 30.1 & 28.3 & 1.68 & 0.3 \\
\hline nitrogen, g/day & $73.2^{\mathrm{cd}}$ & $74.7^{\mathrm{bc}}$ & $79.4^{\mathrm{b}}$ & $95.6^{\mathrm{a}}$ & $71.3^{\mathrm{d}}$ & 1.44 & $<0.0001$ \\
\hline
\end{tabular}

HMG: hay + maize bran + "Magadi"; HCA: hay + maize bran + cassava; HMO: hay + maize bran + molasses; HFC: hay + formulated concentrate; HMB: hay + maize bran

means within rows with different superscripts are statistically different $(\mathrm{P}<0.05)$

TABLE 5

The effect of supplementation with different ingredients on faecal flow and apparent digestibility of $\mathrm{DM}, \mathrm{OM}$, ash and nitrogen

\begin{tabular}{|c|c|c|c|c|c|c|c|}
\hline & \multicolumn{5}{|c|}{ Treatments } & \multirow{2}{*}{ SEM } & \multirow{2}{*}{$P$ value } \\
\hline & HMG & $\mathrm{HCA}$ & HMO & $\mathrm{HFC}$ & HMB & & \\
\hline \multicolumn{8}{|c|}{ Faecal output, $\mathrm{kg} /$ day } \\
\hline $\mathrm{DM}$ & 3.4 & 3.9 & 4.0 & 3.7 & 3.6 & 0.13 & 0.1 \\
\hline $\mathrm{OM}$ & 3.0 & 3.5 & 3.5 & 3.3 & 3.2 & 0.17 & 0.1 \\
\hline ash & $0.40^{\mathrm{ab}}$ & $0.43^{\mathrm{a}}$ & $0.43^{\mathrm{a}}$ & $0.40^{\mathrm{ab}}$ & $0.38^{\mathrm{b}}$ & 0.011 & 0.02 \\
\hline nitrogen & 53.9 & 39.78 & 53.1 & 43.3 & 42.3 & 4.15 & 0.1 \\
\hline \multicolumn{8}{|c|}{ Apparent digestibility, \% } \\
\hline DM & $54.9^{\mathrm{a}}$ & $53.7^{\mathrm{a}}$ & $53.7^{\mathrm{a}}$ & $54.8^{\mathrm{a}}$ & $49.3^{\mathrm{b}}$ & 1.06 & 0.02 \\
\hline $\mathrm{OM}$ & $55.8^{\mathrm{a}}$ & $55.2^{\mathrm{a}}$ & $54.3^{\mathrm{a}}$ & $55.7^{\mathrm{a}}$ & $50.6^{\mathrm{b}}$ & 1.08 & 0.03 \\
\hline nitrogen & $23.6^{\mathrm{b}}$ & $43.8^{\mathrm{ab}}$ & $33.1^{\mathrm{ab}}$ & $52.9^{\mathrm{a}}$ & $37.9^{\mathrm{ab}}$ & 5.51 & 0.04 \\
\hline ash & $47.3^{\mathrm{a}}$ & $37.1^{\mathrm{b}}$ & $48.1^{\mathrm{a}}$ & $44.6^{\mathrm{a}}$ & $35.5^{\mathrm{b}}$ & 1.80 & 0.001 \\
\hline
\end{tabular}

HMG: hay + maize bran + "Magadi"; HCA: hay + maize bran + cassava; HMO: hay + maize bran + molasses; HFC: hay + formulated concentrate; HMB: hay + maize bran means within rows with different superscripts are statistically different $(\mathrm{P}<0.05)$

respectively) while for other treatments, it ranged from 40-43 g/day). Apparent $\mathrm{N}$ digestibility was significantly $(\mathrm{P}=0.04)$ influenced by treatments; being highest with $\mathrm{N}$ supplementation and lowest with "Magadi" supplementation (Table 5).

The intake of NDF was significantly higher with nitrogen, sugar and starch supplementation compared to the control (Table 6). "Magadi" (HMG) and the control (HMB) had similar intake of NDF (4.2 kg/day) (Table 6). 
TABLE 6

The effect of supplementation with different ingredients on neutral detergent fibre (NDF) intake, flow and digestibility

\begin{tabular}{|c|c|c|c|c|c|c|c|}
\hline & \multicolumn{5}{|c|}{ Treatments } & \multirow{2}{*}{ SEM } & \multirow{2}{*}{$\mathrm{P}$ value } \\
\hline & HMG & HCA & HMO & HFC & HMB & & \\
\hline \multicolumn{8}{|l|}{ Neutral detergent fibre (NDF) } \\
\hline intake, $\mathrm{kg} /$ day & $4.16^{\mathrm{c}}$ & $4.35^{\mathrm{bc}}$ & $4.77^{\mathrm{ab}}$ & $5.06^{\mathrm{a}}$ & $4.19^{c}$ & 0.163 & 0.01 \\
\hline duodenal flow, kg/day ${ }^{2}$ & 2.28 & 2.74 & 2.70 & 2.60 & 2.47 & 0.123 & 0.1 \\
\hline faecal flow, $\mathrm{kg} /$ day & 2.01 & 2.47 & 2.39 & 2.27 & 2.19 & 0.105 & 0.1 \\
\hline \multicolumn{8}{|l|}{ digestibility, $\%$} \\
\hline rumen $^{1}$ & $44.8^{\mathrm{ab}}$ & $36.5^{\mathrm{c}}$ & $44.7^{\mathrm{ab}}$ & $48.3^{\mathrm{a}}$ & $42.3^{\mathrm{bc}}$ & 2.10 & 0.02 \\
\hline whole tract & $51.4^{\mathrm{ab}}$ & $43.0^{c}$ & $50.5^{\mathrm{ab}}$ & $54.8^{\mathrm{a}}$ & $47.8^{\mathrm{bc}}$ & 2.10 & 0.02 \\
\hline \multicolumn{8}{|c|}{ Indigestible neutral detergent fibre (INDF) } \\
\hline intake, $\mathrm{kg} /$ day & 1.20 & 1.34 & 1.45 & 1.53 & 1.28 & 0.078 & 0.1 \\
\hline faecal flow, $\mathrm{kg} /$ day & $1.12^{\mathrm{b}}$ & $1.35^{\mathrm{a}}$ & $1.39^{\mathrm{a}}$ & $1.35^{\mathrm{a}}$ & $1.28^{\mathrm{ab}}$ & 0.053 & 0.03 \\
\hline \multicolumn{8}{|c|}{ Digestible neutral detergent fibre (DNDF) } \\
\hline intake, $\mathrm{kg} /$ day & $2.97^{c}$ & $3.02^{b c}$ & $3.34^{\mathrm{ab}}$ & $3.53^{\mathrm{a}}$ & $2.91^{\mathrm{c}}$ & 0.113 & 0.01 \\
\hline duodenal flow, $\mathrm{kg} /$ day $^{3}$ & 1.16 & 1.40 & 1.31 & 1.25 & 1.18 & 0.082 & 0.2 \\
\hline faecal flow, kg/day & 0.89 & 1.10 & 0.99 & 0.92 & 0.92 & 0.070 & 0.2 \\
\hline \multicolumn{8}{|l|}{ digestibility, $\%$} \\
\hline rumen ${ }^{1}$ & $60.9^{\mathrm{a}}$ & $53.0 \mathrm{~b}$ & $61.4^{\mathrm{a}}$ & $64.2^{\mathrm{a}}$ & $59.6^{\mathrm{a}}$ & 2.44 & 0.02 \\
\hline whole tract & $70.0^{\mathrm{a}}$ & $62.6^{\mathrm{b}}$ & $71.1^{\mathrm{a}}$ & $73.4^{\mathrm{a}}$ & $68.9^{\mathrm{a}}$ & 4.46 & 0.02 \\
\hline
\end{tabular}

HMG: hay + maize bran + "Magadi"; HCA: hay + maize bran + cassava; HMO: hay + maize bran + molasses; HFC: hay + formulated concentrate; HMB: hay + maize bran

abc means within rows with different superscripts are statistically different $(\mathrm{P}<0.05)$

1 based on calculated duodenal flow

2 calculated as: Duodenal NDF flow $(\mathrm{kg} /$ day $)=$ Faecal flow NDF $(\mathrm{kg}$ per day $)+(\mathrm{NDF}$ intake per day $\times 0.065$ )

${ }^{3}$ calculated as: Duodenal DNDF flow $(\mathrm{kg} /$ day $)=$ Duodenal NDF flow - Faecal INDF flow (kg/day)

TABLE 7

The effect of supplementation with different ingredients on ruminal fluid $\mathrm{pH}$, volatile fatty acids (VFAs) and ammonia concentration

\begin{tabular}{|c|c|c|c|c|c|c|c|}
\hline & \multicolumn{5}{|c|}{ Treatments } & \multirow{2}{*}{ SEM } & \multirow{2}{*}{$P$ value } \\
\hline & HMG & HCA & HMO & HFC & HMB & & \\
\hline Total VFA, mM & 62.6 & 55.2 & 57.6 & 67.0 & 59.0 & 0.69 & 0.8 \\
\hline \multicolumn{8}{|l|}{ Molar proportions } \\
\hline acetate & $68.4^{\mathrm{c}}$ & $64.8^{\mathrm{a}}$ & $64.8^{\mathrm{a}}$ & $68.8^{\mathrm{c}}$ & $68.0^{\mathrm{bc}}$ & 0.84 & 0.01 \\
\hline propionate & 23.0 & 25.3 & 23.1 & 23.0 & 23.0 & 0.82 & 0.3 \\
\hline butyrate & $8.6^{\mathrm{c}}$ & $10.0^{\mathrm{a}}$ & $12.2^{\mathrm{a}}$ & $8.2^{\mathrm{c}}$ & $9.1^{\mathrm{bc}}$ & 0.41 & $<0.0002$ \\
\hline mean ammonia, mg N/100 ml & $1.75^{\mathrm{b}}$ & $1.58^{\mathrm{b}}$ & $1.09^{\mathrm{a}}$ & $5.70^{\mathrm{c}}$ & $2.24^{\mathrm{b}}$ & 0.515 & $<0.0004$ \\
\hline mean ruminal $\mathrm{pH}$ & 6.7 & 6.7 & 6.8 & 6.5 & 6.6 & 0.08 & 0.2 \\
\hline
\end{tabular}

HMG: hay + maize bran + "Magadi"; HCA: hay + maize bran + cassava; HMO: hay + maize bran + molasses; HFC: hay + formulated concentrate; HMB: hay + maize bran means within rows with different superscripts are statistically different $(\mathrm{P}<0.05)$ 


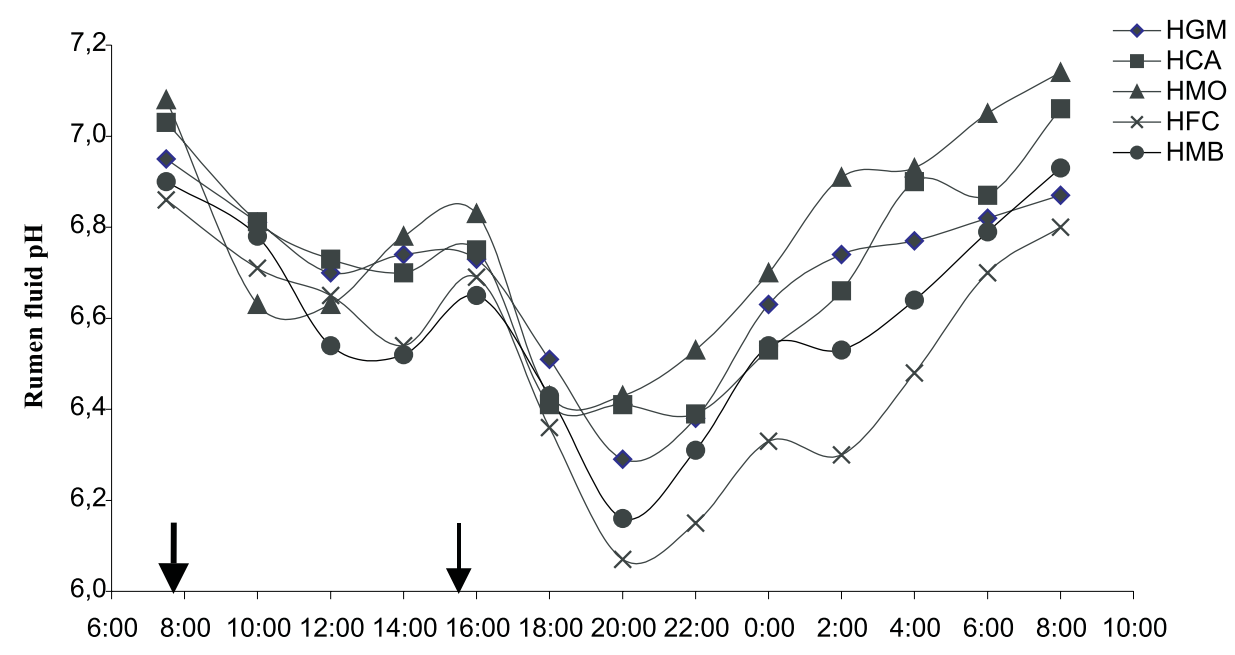

Time of the day

Figure 1. Diurnal variations in the rumen fluid $\mathrm{pH}$ with the various treatments.

Arrows indicate the time when half of the daily amounts of hay and supplements was offered

Calculated duodenal flow and faecal flow of NDF did not differ significantly between the treatments. However, calculated rumen digestibility of NDF and whole tract digestibility was significantly lower $(\mathrm{P}=0.05)$ with starch and significantly higher $(\mathrm{P}=0.05)$ with nitrogen supplementation compared to other treatments (Table 6). Similar trend was observed with digestible NDF.

\section{Rumen fermentation}

Rumen fluid concentration of total acids did not differ significantly between treatments (Table 7). However, the molar proportion of acetate was significantly $(\mathrm{P}=0.01)$ higher with nitrogen (HFC), "Magadi" (HMG) and in the control (HMB) compared to starch (HCA) and sugar (HMO). Sugar and starch supplementation had the highest molar proportion of butyrate compared to the other treatments. No significant effects due to treatments were observed in the rumen fluid $\mathrm{pH}$. Rumen fluid ammonia concentration was significantly $(\mathrm{P}<0.001)$ higher with nitrogen supplementation compared to the other treatments (Table 7).

Figure 1 shows the diurnal variations in the ruminal fluid $\mathrm{pH}$ with the various treatments. Nearly all treatments had a fall in ruminal $\mathrm{pH}$ from 6.9-7.0 just before morning feeding to 6.6-6.8 three hafter feeding with HMB having the lowest $\mathrm{pH}$. A more drastic fall in ruminal $\mathrm{pH}$ occurred just after feeding concentrates at 16:00 reaching lowest levels (6.1) at 20:00 on HFC. 


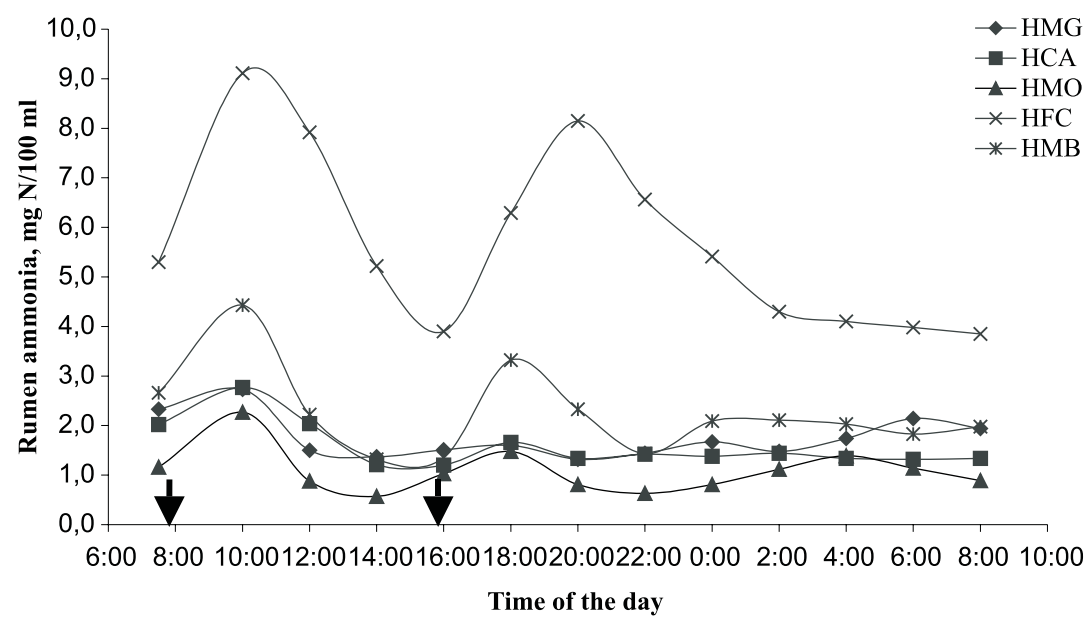

Figure 2. Diurnal variations in the rumen fluid ammonia concentration with the various treatments. Arrows indicate the time when half of the daily amounts of hay and supplements was offered

Diurnal trends in rumen fluid ammonia are shown in Figure 2. Peak ammonia levels (9.1 and $4.4 \mathrm{mg} \mathrm{N} / 100 \mathrm{ml}$ in HFC and HMB, respectively) were attained $2 \mathrm{~h}$ after morning feeding while the levels in the other treatments were between 2.3-2.8 $\mathrm{mg} \mathrm{N} / 100 \mathrm{ml}$ rumen fluid. The evening feeding led to a second ammonia peak (8.2 and $3.3 \mathrm{mg} \mathrm{N} / 100 \mathrm{ml}$ in HFC at 20:00 and in $\mathrm{HMB}$ at 18:00, respectively). Not only were there no ammonia peaks in the other treatments, but the values were also quite low and ranged between 1.0 to $3.0 \mathrm{in} \mathrm{HMG}$ and $\mathrm{HCA}$, and 0.6 to $2.3 \mathrm{mg}$ $\mathrm{N} / 100 \mathrm{ml}$ in HMO. Mean daily ruminal ammonia level (Table 7) was significantly $(\mathrm{P}<0.001)$ higher in HFC compared to the other treatments.

\section{Rumen pool sizes}

Rumen pool sizes of the different fractions were highest with the evening evacuation and lowest in the morning evacuation while the mid-day evacuation had values in between. The mean values for the 3 evacuations are shown in Table 8 .

The DM \% of rumen ingesta was significantly affected by treatments (Table 8 ). The other measured rumen pool parameters seemed not significantly affected by treatments. Values for the average of the three rumen evacuations showed rumen pools of DM (kg) ranging between 8.3 to 9.2, with the lowest and highest value occurring with nitrogen and sugar supplementation, respectively. Mean value of rumen pool sizes ranged from 6.0 to $6.5 \mathrm{~kg}$ for NDF, 3.4 to $4.2 \mathrm{~kg}$ for DNDF and 2.2 to $2.4 \mathrm{~kg}$ for INDF (Table 8). 
TABLE 8

The effect of supplementation with different ingredients on rumen pool sizes of dry ingesta, NDF, INDF, and $\mathrm{N}$ as an average of the three evacuations ( 8 a.m., 12 noon and 5 p.m.)

\begin{tabular}{|c|c|c|c|c|c|c|c|}
\hline & \multicolumn{5}{|c|}{ Treatments } & \multirow{2}{*}{ SEM } & \multirow{2}{*}{ P value } \\
\hline & HMG & HCA & $\mathrm{HMO}$ & $\mathrm{HFC}$ & HMB & & \\
\hline Total ingesta, kg & 60.4 & 55.7 & 60.7 & 55.0 & 59.7 & 1.51 & 0.1 \\
\hline Ingesta DM, \% & $14.0^{\mathrm{c}}$ & $15.3^{\mathrm{a}}$ & $15.1^{\mathrm{ab}}$ & $15.1^{\mathrm{a}}$ & $14.6^{\mathrm{bc}}$ & 0.22 & 0.01 \\
\hline DM ingesta, $\mathrm{kg}$ & 8.5 & 8.6 & 9.2 & 8.3 & 8.8 & 0.31 & 0.4 \\
\hline NDF, kg & 6.0 & 5.7 & 6.5 & 5.8 & 6.1 & 0.26 & 0.3 \\
\hline DNDF, kg & 3.59 & 3.50 & 4.15 & 3.40 & 3.72 & 0.171 & 0.1 \\
\hline INDF, kg & 2.37 & 2.20 & 2.38 & 2.40 & 2.37 & 0.138 & 0.8 \\
\hline $\mathrm{N}, \mathrm{kg}$ & 0.10 & 0.11 & 0.11 & 0.10 & 0.10 & 0.007 & 0.9 \\
\hline
\end{tabular}

HMG: hay + maize bran + "Magadi"; HCA: hay + maize bran + cassava; HMO: hay + maize bran + molasses; HFC: hay + formulated concentrate; HMB: hay + maize bran means within rows with different superscripts are statistically different $(\mathrm{P}<0.05)$

\section{Rates of passage and digestion}

The rate of passage of NDF ranged from 1.65 to $2.10 \% \mathrm{~h}^{-1}$, that of INDF from 1.96 to $2.55 \% \mathrm{~h}^{-1}$ and 1.45 to $1.84 \% \mathrm{~h}^{-1}$ for digestible NDF (Table 9).

TABLE 9

The effect of supplementation with different ingredients on rate of intake, passage, digestion and mean retention time (MRT) in the rumen of NDF

\begin{tabular}{|c|c|c|c|c|c|c|c|}
\hline & \multicolumn{5}{|c|}{ Treatments } & \multirow{2}{*}{ SEM } & \multirow{2}{*}{$\mathrm{P}$ value } \\
\hline & HMG & HCA & HMO & HFC & HMB & & \\
\hline \multicolumn{8}{|c|}{ Neutral detergent fibre (NDF) } \\
\hline intake (ki), $\% \mathrm{~h}^{-1}$ & $2.96^{\mathrm{b}}$ & $3.16^{\mathrm{b}}$ & $3.09^{b}$ & $3.61^{\mathrm{a}}$ & $2.86^{\mathrm{b}}$ & 0.305 & 0.02 \\
\hline passage $(\mathrm{kp}), \% \mathrm{~h}^{-1}$ & $1.65^{\mathrm{b}}$ & $2.10^{\mathrm{a}}$ & $1.78^{b}$ & $1.93^{\mathrm{ab}}$ & $1.75^{\mathrm{b}}$ & 0.076 & 0.02 \\
\hline digestion $(\mathrm{kd}), \% \mathrm{~h}^{-1}$ & $1.31^{\mathrm{b}}$ & $1.05^{\mathrm{b}}$ & $1.31^{\mathrm{b}}$ & $1.68^{\mathrm{a}}$ & $1.10^{\mathrm{b}}$ & 0.105 & 0.01 \\
\hline \multicolumn{8}{|c|}{ Indigestible neutral detergent fibre (INDF) } \\
\hline intake (ki), $\% \mathrm{~h}^{-1}$ & $2.09^{\mathrm{b}}$ & $2.53^{\mathrm{a}}$ & $2.53^{\mathrm{a}}$ & $2.65^{\mathrm{a}}$ & $2.24^{\mathrm{ab}}$ & 0.123 & 0.05 \\
\hline passage $(\mathrm{kp}), \% \mathrm{~h}^{-1}$ & $1.96^{\mathrm{b}}$ & $2.55^{\mathrm{a}}$ & $2.43^{\mathrm{a}}$ & $2.38^{\mathrm{ab}}$ & $2.26^{\mathrm{ab}}$ & 0.123 & 0.05 \\
\hline \multicolumn{8}{|c|}{ Digestible neutral detergent fibre (DNDF) } \\
\hline intake (ki), $\% \mathrm{~h}^{-1}$ & $3.61^{\mathrm{ab}}$ & $3.57^{\mathrm{b}}$ & $3.41^{\mathrm{b}}$ & $4.28^{\mathrm{a}}$ & $3.27^{\mathrm{b}}$ & 0.193 & 0.04 \\
\hline passage $(\mathrm{kp}), \% \mathrm{~h}^{-1}$ & 1.45 & 1.84 & 1.41 & 1.61 & 1.46 & 0.102 & 0.09 \\
\hline digestion $(\mathrm{kd}), \% \mathrm{~h}^{-1}$ & $2.15^{\mathrm{ab}}$ & $1.72^{\mathrm{b}}$ & $1.99^{\mathrm{ab}}$ & $2.66^{\mathrm{a}}$ & $1.81^{\mathrm{b}}$ & 0.182 & 0.02 \\
\hline \multicolumn{8}{|c|}{ Mean retention time (MRT) h } \\
\hline NDF & $60.8^{\mathrm{a}}$ & $47.3^{\mathrm{b}}$ & $57.2^{\mathrm{a}}$ & $52.6^{\mathrm{ab}}$ & $56.9^{\mathrm{a}}$ & 2.39 & 0.03 \\
\hline INDF & 50.7 & 39.6 & 42.0 & 43.3 & 45.0 & 2.51 & 0.08 \\
\hline DNDF & 70.4 & 55.2 & 72.4 & 62.7 & 68.7 & 4.18 & 0.11 \\
\hline
\end{tabular}

HMG: hay + maize bran + "Magadi"; HCA: hay + maize bran + cassava; HMO: hay + maize bran + molasses; HFC: hay + formulated concentrate; HMB: hay + maize bran means within rows with different superscripts are statistically different $(\mathrm{P}<0.05)$ 
The rate of digestion (kd) of NDF and digestible NDF ranged from 1.0 to 1.7 and 1.7 to $2.7 \% \mathrm{~h}^{-1}$, respectively and was significantly $(\mathrm{P}=0.05)$ higher with nitrogen supplementation compared to other treatments. Starch supplementation significantly $(\mathrm{P}=0.01)$ increased the passage rate $(\mathrm{kp})$ of $\mathrm{NDF}$ and also tended to increase $(\mathrm{P}=0.09)$ the passage rate $(\mathrm{kp})$ of digestible NDF compared to other treatments (Table 9). The passage rate of INDF was highest with cassava flour $\left(2.55 \% \mathrm{~h}^{-1}\right)$ and lowest with "Magadi" treatment $\left(1.96 \% \mathrm{~h}^{-1}\right)$.

\section{DISCUSSION}

The hay used was very poor in quality characterised with a low $\mathrm{CP}$ content (3.4\%), high NDF content (75\%) and low in vitro organic matter digestibility $(36.7 \%)$. The high ash content in the hay (11\%) was possibly due to high silica content as frequently observed with mature dry tropical grasses and stovers (Mgheni, 2000) and also due to soil contamination during harvesting. "Magadi" was found to contain mainly minerals and was very rich in water-soluble bicarbonate and may well be very similar to the Magadi soda commercially available from Lake Magadi in Kenya (Nyachoti et al., 1998). The CP content in the concentrate mixture was improved due to the high content of CP in sunflower cake.

The observed higher total DM intake with starch (cassava flour) and sugar (molasses) treatments was expected due to the extra DM from cassava flour $(0.9 \mathrm{~kg})$ and molasses $(1.3 \mathrm{~kg})$. Smallholder farmers asserted that when they used "Magadi", the animals ate more and produced more milk. However, in this study, intake of hay was not increased with "Magadi". This was possibly due to the short adaptation period (14 days). Nangole et al. (1983) observed that it took over a month for cattle not used to Magadi soda soaked maize cob to adapt, and when they did, there was a dramatic increase in both DM intake and overall animal performance, and the maize cobs in their study were ground and soaked in 9\% Magadi soda solution for $24 \mathrm{~h}$ before feeding in contrast to this study where Magadi was sprayed on the hay. Hay intake and apparent $\mathrm{DM}$ and OM digestibility were highest with protein supplementation due to a positive effect in the rumen on rate of digestion of NDF.

The molar proportion of the individual VFAs is highly influenced by the activities of the dominant microbial species in the rumen (France et al., 2000). The observed higher molar proportion of acetate with nitrogen (HFC) and "Magadi" (HMG) supplementation indicated a more cellulolytic rumen environment with those treatments (Czerkawski, 1986). Staples and Lough (1989) noted that in most reported works where bicarbonates are used as a buffering agent in the rumen, the molar proportion of acetate increases. The low molar proportion of acetate and high proportion of butyrate and propionate with molasses and cassava flour feeding were consistent with other findings (Ørskov and Ryle, 1990; Obara et al., 1991) involving high intake of rapidly fermentable carbohydrates. 
The $\mathrm{pH}$ changes (Figure 1) after ingestion of concentrates were expected and followed closely the trend obtained by Khalili and Osuji (1994) in animals fed poor quality hay supplemented with different levels of molasses and also with high concentrate feeding (Devant et al., 2000). Contrary to expectation, the buffering ability due to bicarbonates in "Magadi" was not observed. Ruminal fluid $\mathrm{pH}$ was relatively higher with sugar (molasses) compared to starch (cassava flour). This disagreed with other findings where sugar tended to depress rumen $\mathrm{pH}$ more than starch (Chamberlain and Choung, 1995; Stensig et al., 1998). The reason for this disparity was probably in the amounts offered and the frequency of intake. Since molasses was mixed with the hay, the rate of intake was closely linked with the intake of hay and thus small amounts were consumed at a time. In this study, fermentation of plant fibre seemed not to be affected by $\mathrm{pH}$ since for most part of the day, rumen $\mathrm{pH}$ was above the critical lower limit of 6.0 (Mould et al., 1983) below which fibre digestion starts to be compromised.

Peak ammonia concentration in the rumen fluid occurred for treatment HFC just after feeding the concentrate and also to a small extent in the control (Figure 2). This was expected bearing in mind the high amounts of protein (sunflower) in the concentrate mixture and moderate amounts in the maize bran that had high $\mathrm{N}$ degradation in the rumen. However, only feeding the concentrate mixture resulted in mean rumen ammonia concentration above the minimum recommended level $(5 \mathrm{mg}$ $\mathrm{N} / 100 \mathrm{ml}$ ) for optimum microbial function, though this level is thought to vary widely (Song and Kennelly; 1989; Perdok and Leng, 1990). The cause of the low ruminal ammonia levels with "Magadi" (HMG), starch (HCA) and sugar (HMO) is the low nitrogen content in the feed on these treatments and further a microbial need for synthesis fueled by carbohydrate fermentation and the lowest ammonia concentration also appeared with the highest carbohydrate supplementation (HMO).

The magnitude of rumen pool sizes of different dietary components is influenced by the rates of intake and clearance from the rumen through passage and digestion (Van Soest, 1994). Concentrates are rapidly fermented but plant cell walls (NDF) are slowly fermented and therefore greatly contribute to rumen fill (Madsen et al., 1994). Rumen pool sizes of NDF fractions were not significantly affected by treatments and may be determined more by the rumen fill capacity of the animal and less by the type of feed.

With "Magadi", intake and passage of NDF were slightly lower compared to the control, but the rate of digestion was higher leading to an overall higher NDF digestibility compared to the control (Table 6). The cause of reduced NDF passage from the rumen with "Magadi" treatment was not clear. It might be that the increased ionic concentration of the rumen liquor led to an increase in the buoyancy of NDF particles and therefore reduced passage out of the rumen. The apparently higher mean retention time with "Magadi" treatment may have allowed more time for NDF digestion in the rumen. 
With starch (cassava flour) supplementation, intake of NDF was not much increased but passage rate $(\mathrm{kp})$ was significantly increased and the rate of digestion (kd) decreased (see Table 9). This led to the observed significantly lower calculated rumen and total tract NDF digestibility. The high passage rate of NDF with cassava flour in this study disagreed with the findings of Robinson et al. (1987) where increased starch intake tended to reduce the passage rate of NDF, but the depressing effect of starch on NDF digestion is generally found (Ahmed, 1977).

The commonly observed depressive effect on fibre digestibility associated with molasses feeding (Khalili and Osuji, 1994; Kalmbacher et al., 1995) was not clearly manifested in this study. This was because molasses was sprayed on the hay such that the rate of intake was very slow and therefore small amounts were being consumed at a time. Also, the estimated intake of molasses in this study $(1.3 \mathrm{~kg}$ $\mathrm{DM} /$ animal/day) was below the lower limit of $1.5 \mathrm{~kg} \mathrm{DM} /$ day/animal above which fibre digestibility starts to be compromised (Khalili and Osuji, 1994).

Nitrogen supplementation (HFC) led to higher rate of digestion and a higher intake of NDF than for other treatments, with a moderate rise in passage. The overall effect was higher rumen and total tract NDF digestibility (Table 6). This agreed with the findings of Yan et al. (1996) that moderate supplementation of poor quality roughage with protein rich concentrates improves intake and plant fibre digestibility.

The passage rates of INDF with all the treatments in this experiment were rather high $\left(2.0\right.$ to $\left.2.6 \% \mathrm{~h}^{-1}\right)$. However, they were generally lower than those reported by Mgheni (2000) (1.17 to $3.48 \% \mathrm{~h}^{-1}$ ) in heifers fed either hay, maize silage or urea treated straw under tropical conditions. Stensig (1996) obtained passage rate of INDF in cows fed either lucerne silage or timothy silage mixture supplemented with graded levels of sugar or starch that were much lower $\left(1.4\right.$ to $\left.1.8 \% \mathrm{~h}^{-1}\right)$ compared to those obtained in this study. The disparity was expected bearing in mind the great differences in breed, environment, treatments, sources of NDF and intake levels in the reported works. However, the greatest contributory factor of the high INDF passage rate observed in this study was probably the high level of intake relative to body size $\left(75-112 \mathrm{~g} / \mathrm{W}^{0.75}\right)$ of the animals used in this trial. High intake level exerts some pushing effect on passage.

The passage rate of INDF was much higher than that of NDF that was in turn higher than that of DNDF. This was consistent with literature findings (Huhtanen, 1998; Stensig et al., 1998; Mgheni, 2000). Such findings agreed with the general understanding that potentially digestible fibre component undergoing fermentation has low functional specific gravity due to gases formed around and inside particles thereby making them more buoyant and less likely to pass out of the rumen (Tamminga et al., 1989). On the other hand, after long stay in the rumen, particle size decreases due to digestion and mastication leading to an increase in the proportion of indigestible component while the amount of gas falls making the 
particles more dense and thus more liable to pass out of the rumen (Allen, 1996). Therefore, the simple one-compartment model on which the rumen evacuation is based is not entirely correct due to inability to take into consideration the selective retention of newly ingested NDF containing materials (Huhtanen, 1998).

As reported elsewhere (Stensig, 1996; Stensig et al., 1998) the 100\% post ruminal recovery of INDF is hard to achieve. In this study, faecal recovery of INDF was 93.3, $100.8,95.9,88.2$ and 100\% with "Magadi", starch, sugar, concentrate mixture and maize bran treatments, respectively. The less than $100 \%$ recovery of INDF indicate that proper collection of the faeces from the floor was a problem especially the soft faeces when the animals are fed the concentrates.

A more realistic comparison of the kinetics of NDF is obtained when the indigestible fraction is removed from NDF to obtain digestible NDF (Allen and Mertens, 1988). However, almost similar scenario as for the NDF appeared for digestible NDF. Of all treatments, the nitrogen supplementation (HFC) had the highest DNDF digestibility due to an increase in the rate of digestion, with a slight increase in the rate of passage and the intake of DNDF. This was mainly caused by enhanced cellulolytic activity due to more uniform availability of $\mathrm{N}$ (ammonia) throughout the day compared to the other treatments where ammonia availability was limiting fibre degradation.

\section{CONCLUSIONS}

This study proved that the major limiting factor for intake, digestibility and therefore efficient utilization of poor quality forage was nitrogen availability in the rumen. Therefore, it is of outmost importance for smallholder dairy farmers who use energy rich supplements like sugar (molasses) and starch (cassava) to concurrently provide nitrogen sources like sunflower cake, which is easily available locally. However, for farmers who do not have access to sources of nitrogen, molasses and cassava can still be used provided they do not give more than $2 \mathrm{~kg}$ DM of either supplement per animal/day.

Appropriate amounts or combinations of energy and protein supplements as well as feed additives to optimize intake and digestibility of fibre in the basal diet is still an area where further research is needed.

\section{ACKNOWLEDGEMENTS}

The authors would like to thank M. Mbwana and W. Kibirige of Sokoine University and Ejner Serup, Edith Olsen and Hanne Pedersen from Danish Institute 
of Agricultural Sciences at Foulum, Denmark for their technical support. We also express our sincere thanks to the Danish Government for sponsoring this work through DANIDA.

\section{REFERENCES}

Ahmed F.A., 1977. Feeding cassava to cattle as energy supplement to dried grass. East Afr. Agr. Forest. J. 42, 368-372

Allen M.S., 1996. Physical constraints on voluntary intake of forages by ruminants. J. Anim. Sci.74, 3063-3075

Allen M.S., Mertens D.R., 1988. Evaluating constraints of fibre digestion by rumen microbes. J. Nutr. 118, 261-270

AOAC, 1990. Associations of Official Argicultural Chemists, Official Methods of Analysis.15th Edition. Washington D.C. Vol. 1, pp. 62

Beever D.E., Siddon R.C., 1986. Digestion and metabolism in grazing ruminant. In: L.P. Miligan, W.L. Grovum, A. Dobson (Editors). Control of Digestion and Metabolism in Ruminants. Prentice Hall, Englewood Cliffs, NJ, pp. 479-497

Chamberlain D.G., Choung J.J., 1995. The importance of the rate of ruminal fermentation of energy sources for the diet of dairy cows. In: P.C. Garnswothy, D.J.A Cole (Editors). Recent Advances in Animal Nutrition. Nottingham University Press (UK), pp. 3-27

Chaney A.L., Marbach A.P., 1962. Modified reagents for determination of urea and ammonia. Clin. Chem. 8, 130

Cronje P.B., Nolan J.V., Leng R.A., 1991. Acetate clearance rates as a potential index of the availability of glucogenic precursors in ruminants fed on roughage based diets. Brit. J. Nutr. 66, 301-312

Czerkawski J.W., 1986. An Introduction to Rumen Studies. Pergamon Press, Oxford (UK), pp. 226

Dado R.G., Allen M.S., 1995. Intake limitations, feeding behaviour, and rumen functions of cows challenged with rumen fiber dietary inert bulk. J. Dairy Sci. 78, 118-133

Devant M., Ferret A., Gasa J., Calsamiglia S., Casalas R., 2000. Effects of protein concentration and digestibility on performance, ruminal fermentation and nitrogen metabolism in rapidly growing heifers fed a high concentrate diets from 100 to $230 \mathrm{~kg}$ body weights. J. Anim. Sci. $78,1667-1676$

France J., Theodorou M.K., Lowman R.S., Beever D.E., 2000. Feed evaluation for animal production. In: J. France, M.K. Theodorou (Editors). Feeding Systems and Feed Evaluation Models. CABI Publishing, NY (USA), pp. 1-10

Göhl B., 1981. Tropical feeds. Feed Information and Nutritive Values. FAO, Rome, pp. 529

Huhtanen P., 1998. Digestion and passage kinetics of fibre. In: Proceedings from a Seminar held at the Swedish University of Agricultural Science, Karoline - Model for Feed Evaluation, pp. 38-49

Kalmbacher R.S., Brown W.F., Pate F.M., 1995. Effects of molasses based liquid supplement on digestibility of creeping bluestem and performance of mature cows on winter range. J. Anim. Sci. 73, 853-860

Khalili H., Huhtanen P., 1991. Sucrose supplements in cattle given grass silage-base diets. 2. Digestion of cell wall carbohydrates. Anim. Feed Sci. Tech. 33, 263-273

Khalili H., Osuji P.O., 1994. The effect of replacement of wheat bran by graded levels of molasses on digestion, degradation and digestion kinetics of fibre and rumen digesta pool size in crossbred (Bos taurus $x$ Bos indicus) steers fed native grass hay. Anim. Feed Sci. Tech. 47, 213-223 
Leng R.A., 1990. Factors affecting the utilisation of poor quality forages by ruminants particularly under tropical conditions. Nutr. Res. Rev. 3, 277-303

Madsen J., Stensig T., Weisbjerg M.R., Hvelplund T., 1994. Estimation of the physical fill of feedstuffs in the rumen by the in sacco degradation characteristics. Livest. Prod. Sci. 39, 43-47

Mgheni D.M., 2000. Prediction of intake of tropical forages in dairy cattle based on studies from fibre digestion kinetics. PhD. Thesis, Sokoine University of Agriculture, pp. 210

Mould F.L., Ørskov E.R., Mann S.O., 1983. Associative effects of mixed feeds. 1. Effects of type and level of supplementation on the influence of rumen $\mathrm{pH}$ on cellulolysis in vivo and dry matter digestion of various roughages. Anim. Feed Sci. Tech. 10, 15-30

Nangole F.N., Kayongo M.H., Said A.N., 1983. Chemical composition, digestibility and feeding value of maize cob. Anim. Feed Sci. Tech. 9, 121-130

Nolan J.V., 1990. Nitrogen kinetics. In: F.M. Forbes, F. France (Editors). Quantitative Aspects of Ruminants Digestion and Metabolism. CAB International Willingford, Willingford (UK), pp. 123-143

Nyachoti C.M., Atkinson J.L., Leeson S., 1998. Evaluation of Magadi soda treated sorghum grain for young broilers. Anim. Feed Sci. Tech. 70, 295-304

Obara Y., Dellow D.W., Nolan J.V., 1991. The influence of energy rich supplements on nitrogen kinetics in the rumen. In: T. Tsuda, Y. Sasaki, R. Kawashima (Editors). Physiological Aspects of Digestion and Metabolism in Ruminants. Academic Press Inc. San Diego, pp. 484-533

Ørskov R.E., Ryle M. (Editors), 1990. Energy Nutrition in Ruminants. Elsevier Applied Science, London, New York, pp. 149

Perdok H.B., Leng R.A., 1990. Effects of supplementation with protein meal on the growth of cattle given a basal diet of untreated or ammoniated rice straw. Asian-Austr. J. Agr. Sci. 3, 269-279

Poppi D.P., McLennan R.S., 1995. Protein and energy utilisation by ruminants at pasture. J. Anim. Sci. 73, 278-290

Preston T.R., Leng R.A., 1987. Matching Ruminant Production Sytems with the Available Resources in the Tropics. Penambul Books: Armidale, N.S.W., pp. 249

Richardson A.J., Calder A.G., Stewart C.S., Smith A., 1989. Simultaneous determination of volatile and non-volatile acidic fermentation products of anaerobes by capillary gas chromatography. Lett. Appl. Microbiol. 9, 5-8

Robinson P.H., Tamminga S., Van Vuuren A.M., 1987. Influence of declining level of feed intake and varying proportion of starch in the concentrate on rumen ingesta quantity, composition and kinetics of ingesta turnover in dairy cows. Livest. Prod. Sci. 17, 37-62

SAS, 1988. Statistical Analysis System Institute, SAS Institute Inc, Cary, NC (USA)

Shayo C.M, Ogle, B., Uden, P., 1997. Comparison of water melon (Citrullus vulgaris) seed meal, Acacia tortilis pods and sunflower-seed cake supplements in central Tanzania. 2. Effect on hay intake, milk yield and composition of Mpwapwa cows. Trop. Grasslands 31, 130-134

Song M.K., Kennelly J.J., 1989. In situ degradation of feed ingredients, fermentation pattern and microbial population as influenced by ruminal ammonia concentration. Can. J. Anim. Sci. 69, 999-1006

Staples C.R., Lough D.S., 1989. Efficacy of supplemental dietary neutralising agents for lactating dairy cows. A review. Anim. Feed Sci. Tech. 23, 277-303

Stensig T., 1996. Digestion and passage kinetics of forage fibre in dairy cows. PhD. Thesis. The Royal Veterinary and Agricultural University, Copenhagen (Denmark), pp. 139

Stensig T., Weisberg M.R., Hvelplund T., 1998. Evaluation of different methods for the determination of digestion and passage rates of fibre in the rumen of dairy cows. Acta Agr. Scand., Sect. A, Anim. Sci. 48, 141-154

Tamminga S., Robinson P.H., Voigt M., Boer H., 1989. Rumen kinetics of cell wall components in dairy cows. Anim. Feed Sci. Tech. 25, 89-98 
Tilley J.M.A., Terry R.A., 1963. A two stage technique for the in vitro digestion of forages. J. Brit. Grassl. Soc. 18, 104-111

Van Soest P.J., 1994. Nutritional Ecology of the Ruminant Animal. 2nd Edition. Comstock Publishing Associates, Ithaca and London, pp. 475

Van Soest P.J., Robertson J.B., Lewis B.A., 1991. Methods for dietary fibre, neutral detergent fibre and non-starch polysaccharides in relation to animal nutrition. J. Dairy Sci. 74, 3583-3597

Yan T., Offer N.W., Roberts D.J., 1996. Effects of dietary nitrogen sources and the level on rumen fermentation, nutrient degradation and digestion and microbial activity by wether sheep given a high level of molasses. J. Anim. Sci. 63, 123-131

\section{STRESZCZENIE}

\section{Wpływ dodatku cukru, skrobi, mieszanki treściwej i mineralnej na pobranie paszy, kinetykę funkcji żwacza i NDF u dorosłych jałówek otrzymujących złej jakości siano w Tanzanii}

Badano wpływ tradycyjnie stosowanych w małych fermach mlecznych składników dawki pasz na funkcje żwacza, a mianowicie: otrąb kukurydzianych, melasy, tapioki, makuchu słonecznikowego i preparatu mineralnego „Magadi”. Doświadczenie wykonane na 5 jałówkach $\left(1 \frac{1}{2}\right.$ Boran $\times 1 \frac{1}{2}$ fryzyjska) w układzie $5 \times 5$ kwadratu łacińskiego składało się z 14 dni adaptacji, 7 dni oznaczania strawności składników pokarmowych oraz 7 dni przeznaczonych na ewakuacje treści żwacza. Jałówki grupy kontrolnej żywiono dawkami pasz stosowanymi w praktyce, składającymi się ze złej jakości siana oraz $2,7 \mathrm{~kg}$ (s.m.) otrąb kukurydzianych (HMB). W pozostałych grupach skarmiano dawkę podstawową z dodatkiem, odpowiednio, $0,25 \mathrm{~kg}$ (s.m.) preparatu „Magadi” (HMG), 1,3 kg (s.m.) cukru (melasa) (HMO), 0,9 kg (s.m.) skrobi w postaci tapioki (HCA) lub 2,8 kg (s.m.) sporządzonej na farmie mieszanki treściwej zawierającej (\% s.m.): otręby kukurydziane - 68; makuch słonecznikowy - 31; mieszankę mineralną - 1 .

Pobranie suchej masy paszy przy skarmianiu dawki z dodatkiem cukru (HMO), skrobi (HCA) lub białka (HFC) było istotnie większe $(\mathrm{P}<0,01)$ niż w grupie kontrolnej (HMB). Strawność suchej masy i masy organicznej wynosiła od 49 do $56 \%$ i była istotnie większa $(\mathrm{P}<0.05)$ przy skarmianiu dawek z dodatkiem paszy białkowej (HFC), „Magadi” (HMG), cukru (HMO) i skrobi (HCA) niż $\mathrm{w}$ grupie kontrolnej. Rodzaj dodatku nie wpływał na wartość pH płynu żwaczowego, natomiast stężenie amoniaku było istotnie $(\mathrm{P}<0,001)$, a LKT nieco większe $(\mathrm{P}<0,1)$ u zwierząt grupy HFC niż w innych grupach. Proporcja molarna zawartości kwasu octowego w LKT była istotnie większa $(\mathrm{P}=0,05)$ w grupach HFC $(68,8 \%), \mathrm{HMG}(68,4 \%)$ i HMB $(68,0 \%)$ niż w grupach HMO i HCA (65\%). Tempo i ilość trawionego NDF było istotnie większe $(\mathrm{P}=0,02)$ przy skarmianiu dawek z dodatkiem białka (HFC) $\left(2,66 \% \mathrm{~h}^{-1}\right.$ i $62,4 \%$, odpowiednio), a istotnie niższe $(\mathrm{P}=0,01)$ przy dodatku skrobi (HCA) (1,72\% i 53,0\%, odpowiednio) niż w pozostałych grupach. Przy skarmianiu dawek ze skrobią stwierdzono największe tempo przepływu nie trawionego NDF $\left(2,55 \% \mathrm{~h}^{-1}\right)$; było ono istotnie większe niż w grupie kontrolnej.

Uzyskane dane wskazują, że złej jakości siano jest lepiej wykorzystywane przy większej dostępności azotu w żwaczu oraz, że dodatek cukru, skrobi i preparatu mineralnego „Magadi” mają zmienny wpływ na pobranie i strawność złej jakości siana. Jednakże, jeżeli dostępne są tanie źródła cukru i skrobi mogą być one stosowane bez znacznego obniżenia strawności dawki podstawowej. 